\title{
Effect of peroxide treatment on the structure and transparency of bacterial cellulose film
}

\author{
Heru Suryanto ${ }^{1,2, *}$, Tito Arif Sutrisno ${ }^{1}$, M. Muhajir ${ }^{1}$, Neena Zakia ${ }^{3}$, and Uun Yanuhar $^{4}$ \\ ${ }^{1}$ Master Program of Mechanical Engineering, Graduate School, Universitas Negeri Malang, 65145 \\ Malang, Indonesia \\ ${ }^{2}$ Mechanical Engineering Department, Engineering Faculty, Universitas Negeri Malang, 65145 \\ Malang, Indonesia \\ ${ }^{3}$ Chemical Department, Mathematics and Natural Sciences Faculty, Universitas Negeri Malang, \\ 65145 Malang, Indonesia \\ ${ }^{4}$ Fisheries and Marine Sciences Faculty, Brawijaya University, 65145 Malang, Indonesia
}

\begin{abstract}
The cellulose extracts from plants are need of energy and have potential in damaging the environment so that an alternative cellulose source with more efficient results is by using bacteria to produce the cellulose fibers. This study aims to determine the effect of hydrogen peroxide $\left(\mathrm{H}_{2} \mathrm{O}_{2}\right)$ treatment on the structure and transparency of biopolymer bacterial cellulose film (BCF). The method used is the making of BCF by utilizing pineapple peel extract and then cooking at $80^{\circ} \mathrm{C}$ for 120 min. with $\mathrm{H}_{2} \mathrm{O}_{2}$ concentration of $0 \%, 2.5 \%, 5 \%$, and 7,5\%. Drying is done in the electric oven and then observed the structure and morphology using X-ray diffraction and transparency test, respectively. The result of structure observation shows that the intensity of the highest diffraction peak lies at a diffraction angle of $22^{\circ}$ achieved at $5 \%$ peroxide treatment with crystallinity and crystal index of $85.1 \%$ and $82.4 \%$, respectively. Transparency testing shows that the higher the concentration of peroxide used, the better the transparency.
\end{abstract}

\section{Introduction}

Now a day, the materials from nature, especially fiber, have been applied in the biocomposites form for various technological devices that are easily decomposed. Cellulose from bacteria has unique characteristics and is relatively purer because in the absence of hemicellulose and lignin [1-2]. Cellulose from plants is considered impure because it contains many types of complex carbohydrates, wherein cellulose derived from plants has its components comprising hemicellulose (20-35\%), cellulose (35-50\%), and lignin (10$25 \%)$ [3].

Bacterial cellulose (BC) can be produced from a number of fruit extracts, including oranges, apples, pears, pineapples, tomatoes and coconuts [4] [5]. One of the products that can be derived from pineapple waste is the nata. The nata is a product of fermentation of sugar (glucose) by Acetobacter xylinum which is then converted into cellulose. BC has

\footnotetext{
* Corresponding author: heru.suryanto.ft@um.ac.id
} 
formed a thin layer of transparent mucus on the surface that thickens with age to form a thick sheet of white after 10-15 days culture [5].

$\mathrm{BC}$ is increasingly used because it has many advantages such as food, filtration membrane, paper, plastic and biomedical [6-10]. BC is a biopolymer containing glucose, fructose, sucrose, mannitol [11] with better material properties, such as purity, high porosity, high permeability relative to liquids and gases, high water absorption capacity, tensile strength and ultrafine tissue [9]. BC has a network of very fine fibers with a diameter of $20-100 \mathrm{~nm}[8,10]$. It has a high surface activity because it consists of fibrils network and its tensile strength and modulus elastic can reach $128 \mathrm{MPa}$ [12] and $30 \mathrm{GPa}$ [13].

Bleaching technology is also currently widely studied in the process of BC treatments. The hydrogen peroxide solution produces a clean white product and the bleached organic material is damaged very little and is not even damaged and the process is environmentally friendly and highly efficient [14]. The main goal of treatment in BCF is for the removal of amorphous content in BCF. Therefore, aims of the study are to determine the effect of hydrogen peroxide $\left(\mathrm{H}_{2} \mathrm{O}_{2}\right)$ treatment on the structure and transparency of biopolymer BCF.

\section{Method}

\subsection{Materials}

In this study, the production of BC conducted the bacteria strain of Acetobacter xylinum, supplied by the Nano Research Advanced Material Laboratory, Mechanical Engineering Department, Malang, Indonesia. Extract of pineapple peel waste was applied as the main medium for the culture of bacteria for BC production. The chemical compounds, i.e. ammonium sulfate $\left(\left(\mathrm{NH}_{4}\right)_{2} \mathrm{SO}_{4}\right)$, acetic acid $\left(\mathrm{CH}_{3} \mathrm{COOH}\right)$, and sodium hydroxide $(\mathrm{NaOH})$, provided from UD Sumber Ilmiah Malang (Indonesia).

\subsection{Synthesis of bacterial cellulose film}

The culture medium for the $\mathrm{BC}$ production was according to the procedure from Retegi et al. [15]. The culture medium of BC consists of 2,000 ml pineapple peel extract, $10 \%$ sugar, $0.5 \%$ ammonium sulfate, and $5 \%$ acetic acid (v/v) adjusted to get a pH of $4.5 .10 \%(\mathrm{v} / \mathrm{v})$ bacteria starter was added to the culture medium, then incubated for 10 days at $30^{\circ} \mathrm{C}$ under static conditions. After incubation process, the bacteria formed a pellicle on the surface of the medium then harvested and rinsed with distilled water for removal of impurities and residual medium components.

\section{$2.3 \mathrm{H}_{2} \mathrm{O}_{2}$ Treatment}

$\mathrm{BC}$ pellicle was obtained from a bacterial culture age of 14 days. Treatment of $\mathrm{BC}$ is conducted by boiling $\mathrm{BC}$ pellicle in water to remove bacterial and acidic substances, then washing it using distilled water. BC pellicle was divided into 4 parts subsequently immersing the bacterial cellulose with 4 variations of $100 \mathrm{ml} \mathrm{H}_{2} \mathrm{O}_{2}$ solution with a concentration of $0 \%, 2.5 \%, 5 \%$, and $7.5 \%$ in the beaker glass so that $\mathrm{BC}$ pellicle can be submerged perfectly. Warm up the BC using magnetic stirrer (SP131320-33 type, Thermo Scientific) with $600^{\circ} \mathrm{C}$ and $100 \mathrm{rpm}$. BC rinsed with distilled water to remove the $\mathrm{H}_{2} \mathrm{O}_{2}$ content. Drying $\mathrm{BC}$ in the oven for 4 hours at $80^{\circ} \mathrm{C}$. Before being put in the oven, $\mathrm{BC}$ attached to a clamp to get a good cellulose sheet. This process described in Figure 1. 


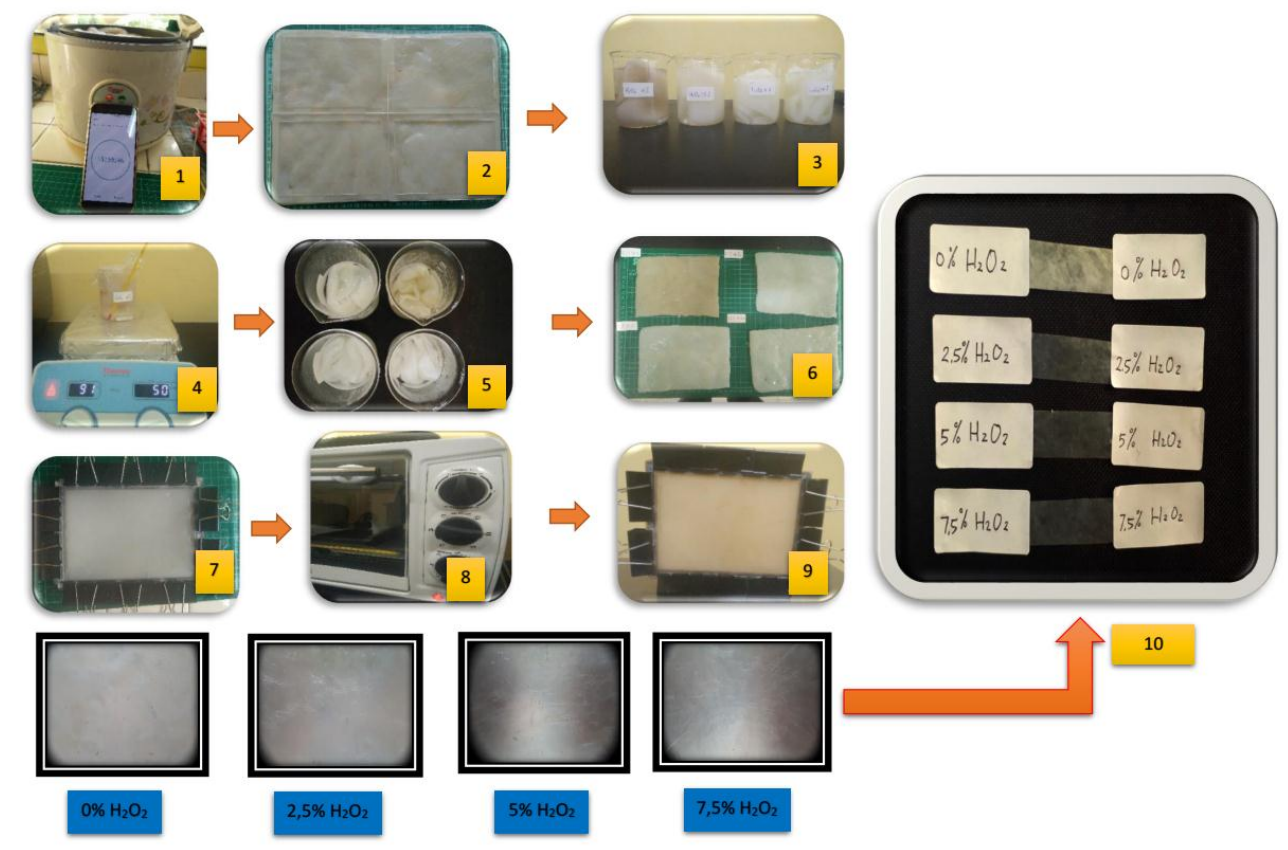

Fig. 1. The treatment process of $\mathrm{BC}$ using $\mathrm{H}_{2} \mathrm{O}_{2}$.

\subsection{Transparency analysis}

Transparency analysis is done by placing the BCF on a black cloth and then photographed with the camera. Transparency analysis is done by color quantification with standard 8-bit monochrome image / grayscale image color image (intensity of 0 as solid black color while the intensity of 255 as bright white color) [16] with ImageJ 1.44 software by comparing with synthetic control (the new transparent plastic film). Measurement of transparency is carried out on an area of $10 \mathrm{~cm}^{2}$.

\subsection{X-ray diffraction analysis (XRD)}

XRD analysis was applied to determine the crystallinity and crystallinity index of the BCF. XRD patterns were recorded using a PanAnalitycal diffractometer at the wavelength of $\mathrm{CuK} \alpha$ radiation $(\lambda)$ of $1.54 \AA$, generated at $40 \mathrm{kV}$ and $30 \mathrm{~mA}$ [17]. Samples were scanned in a $2 \theta$ range from $5^{\circ}$ to $50^{\circ}$ with a step size of $0.02^{\circ}$. Data were analyzed by the Origin software. The crystallinity index $(\mathrm{CrI})$ and crystallinity $(\% \mathrm{Cr})$ was determined using the Segal empirical formula:

$$
\begin{aligned}
& \% C r=\frac{I_{\left(\begin{array}{lll}
0 & 2
\end{array}\right)}}{I_{(a m)}+I_{\left(\begin{array}{lll}
0 & 0
\end{array}\right)}} \times 100 \%
\end{aligned}
$$

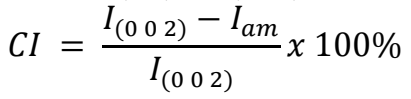

where, $\mathrm{I}_{\mathrm{am}}$ is the diffraction intensity at $2 \theta\left(\approx 23^{\circ}\right)$ and $\mathrm{I}_{002}$ is the maximum diffraction intensity of the (002) lattice. 


\section{Results and Discussion}

\subsection{XRD Analysis}

Results of XRD scanning for BCF is shown in Figure 1. According to the XRD analysis data, the crystallinity was calculated and summarized in Table 1.

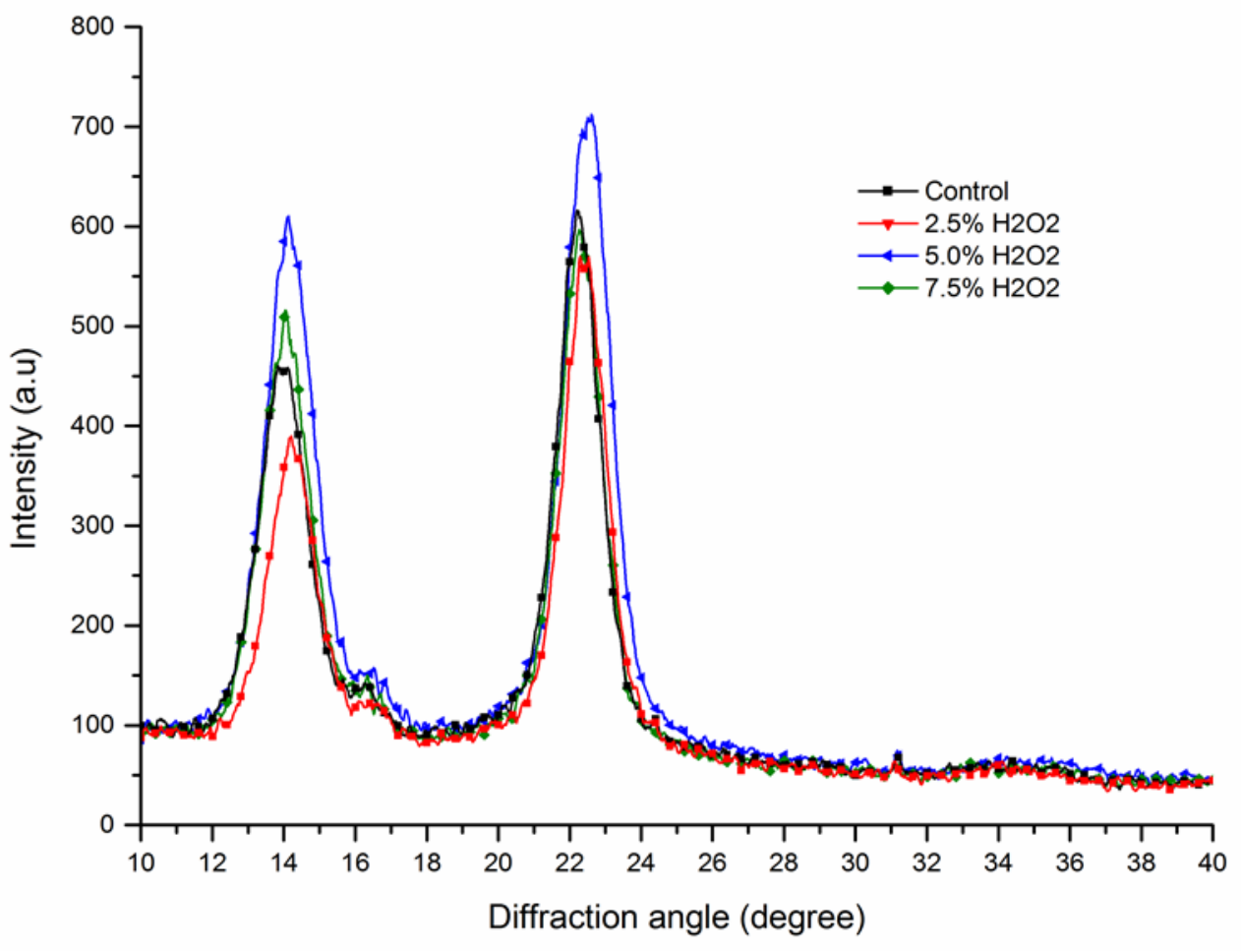

Fig. 2. The X-ray diffraction patterns of the samples of BCF.

Figure 2 shows the diffractogram of the four BCF samples. The results of X-ray diffraction representing the $\mathrm{BC}$ structure. The diffraction pattern of the $\mathrm{BCF}$ treated in different peroxide concentration revealed three diffraction peaks with high intensity at an angle of $2 \theta: 14.2^{\circ}$ and $22.6^{\circ}$ and a peak with small intensity at $16.8^{\circ}$, The amorphous portion of the BCF structure is shown at a valley among two peaks in the diffractogram, about $18^{\circ}$. BCF structure was represented by the diffraction angles from $22^{\circ}$ to $23^{\circ}$ that is the character of the cellulose I (original cellulose) [18]. The diffraction peaks indicating other types of cellulose I were peaks of the diffraction angle of $14.9^{\circ}$ and $16.7^{\circ}$ for the structure of cellulose I $\beta$ while the peaks of the diffraction angle of $14.3^{\circ}$ and $16.8^{\circ}$ for the structure the cellulose I $\alpha$ [19]. Therefore, the type of BCF structure peak produced from bacteria is cellulose I $\alpha$.

After treatment of peroxide solution, the crystallinity of BCF was an increase because amorphous have dissolved in a peroxide solution. The highest crystallinity percentages were $85.1 \%$, which were produced from the treatment of peroxide $5 \%$. 
Table 1. Effect of treatment of peroxide on the crystalline structure of $\mathrm{BCF}$

\begin{tabular}{|l|c|c|c|c|}
\hline \multirow{2}{*}{ Component } & \multicolumn{4}{|c|}{ The concentration of peroxide (\%) } \\
\cline { 2 - 5 } & $\mathbf{0 \%}$ & $\mathbf{2 , 5 \%}$ & $\mathbf{5 \%}$ & $\mathbf{7 , 5 \%}$ \\
\hline $2 \square\left(^{\circ}\right)$ & 22.249 & 22.4091 & 22.7404 & 22.2753 \\
\hline I002 & 464.56 & 420.45 & 542.55 & 454.44 \\
\hline Iam $\left(^{\circ}\right)$ & 95.04 & 80.69 & 95.28 & 82.5 \\
\hline$\% \operatorname{Cr}(\%)$ & 83.0 & 83.9 & 85.1 & 84.6 \\
\hline $\operatorname{CrI}(\%)$ & 79.5 & 80.8 & 82.4 & 81.8 \\
\hline
\end{tabular}

\subsection{Tranparency Analysis}

The transparency test results are based on the photograph of treated BCF as shown in Figure 3, while the color quantification results are shown in Table 2.
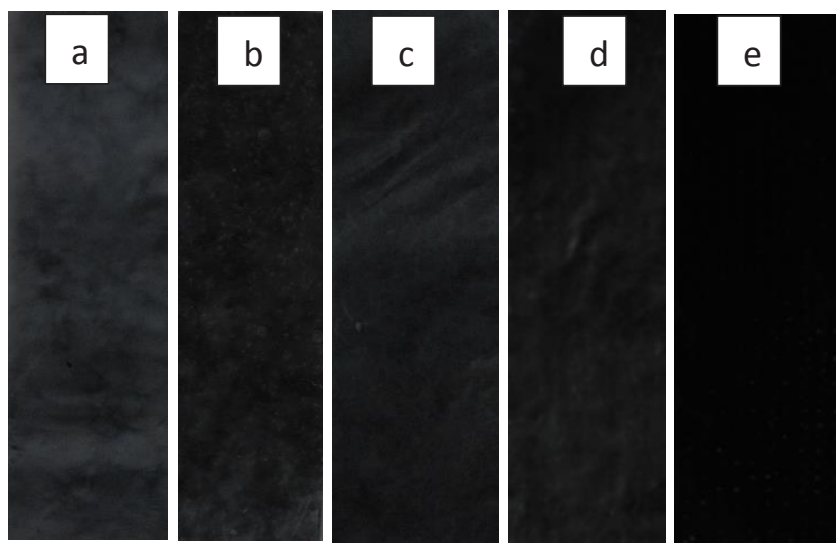

Fig. 3. Transparency of $\mathrm{BCF}$ after treated by $\mathrm{H}_{2} \mathrm{O}_{2}$ at concentration of: a. $(0 \%)$ b. $(2.5 \%)$ c. $(5 \%)$ d. $(7.5 \%)$, and e (transparent syntetic plastic as control).

Table 2. Transparency analysis of BCF treated by peroxide solution

\begin{tabular}{|l|c|c|}
\hline \multicolumn{1}{|c|}{ Tested film } & $\begin{array}{c}\text { Mean color } \\
\text { quantification }\end{array}$ & Transparency (\%) \\
\hline $0 \% \mathrm{H}_{2} \mathrm{O}_{2}$ & 64.789 & 78.42 \\
\hline $2,5 \% \mathrm{H}_{2} \mathrm{O}_{2}$ & 39.874 & 88.70 \\
\hline $5 \% \mathrm{H}_{2} \mathrm{O}_{2}$ & 35.281 & 90.59 \\
\hline $7,5 \% \mathrm{H}_{2} \mathrm{O}_{2}$ & 30.968 & 92.37 \\
\hline Synthetic plastic (control) & 12.455 & 100.00 \\
\hline
\end{tabular}

Note: 0 = full black; 255 = full white

Transparency test analysis using Image J software showed that the lower the concentration of $\mathrm{H}_{2} \mathrm{O}_{2}$, the transparency level is lower. $\mathrm{BC}$ without treatment and with treatment by $\mathrm{H}_{2} \mathrm{O}_{2}$ solution with concentration of $2.5 \%, 5.0 \%$, and $7.5 \%$ shows the color intensity of 64.789 ; $39.874 ; 35.281$; and 30.968 , with transparency of $78.42 \%, 88.7 \%, 90.59 \% ; 92.37 \%$, respectively and as its reference is the level of transparency $100 \%$ of the plastic shows the color intensity of 12.455 . 


\section{Conclusion}

The treatments using various concentration of $\mathrm{H}_{2} \mathrm{O}_{2}$ solution on $\mathrm{BCF}$ had conducted. $\mathrm{H}_{2} \mathrm{O}_{2}$ solution able to increase crystallinity and crystalline index of BCF increasing transparency level of $\mathrm{BCF}$. This finding is expected to provide basic information useful to those who use $\mathrm{BCF}$ for further applications in the packaging or other fields.

The financial support from Universitas Negeri Malang through the PNBP fund with contract no. 2.3.147/UN32.14/LT/2018 is gratefully acknowledged.

\section{References}

1. K. Syamsu and T. Kuryani, J. Agroindustri Indones, 3 126-133 (2014)

2. I. Reiniati, A. N. Hrymak, and A. Margaritis, Crit. Rev. Biotechnol, 37 510-524 (2017)

3. A. Junka, K. Fijałkowski, A. Ząbek, K. Mikołajewicz, G. Chodaczek, P. Szymczyk, D. Smutnicka, A. Żywicka, P. P. Sedghizadeh, M. Dziadas, P. Młynarz, and M. Bartoszewicz, Carbohydr. Polym, 157 371-379 (2017)

4. P. Lestari, N. Elfrida, A. Suryani, and Y. Suryadi, Jordan J. Biol. Sci, 7 75-80 (2014)

5. A. Jagannath, P. S. Raju, and A. S. Bawa, LWT - Food Sci. Technol, 43 1197-1203 (2010)

6. M. Zeng, A. Laromaine, and A. Roig, Cellulose, 21 4455-4469 (2014)

7. S. P. Lin, I. Loira Calvar, J. M. Catchmark, J. R. Liu, A. Demirci, and K. C. Cheng, Cellulose, 20 2191-2219 (2013)

8. C. Babac, T. Kutsal, and E. Piskin, Int. J. Nat. Eng. Sci, 3 19-29 (2009)

9. M. E. Fuller, C. Andaya, and K. McClay, J. Microbiol. Methods, 144 145-151 (2018)

10. Y. Dahman, J. Nanosci. Nanotechnol, 9 5105-5122 (2009)

11. C. Castro, R. Zuluaga, C. Álvarez, J. L. Putaux, G. Caro, O. J. Rojas, I. Mondragon, and P. Gañán, Carbohydr. Polym, 89 1033-1037 (2012)

12. M. Karina, L. Indrarti, R. Yudianti, Indriyati, and A. Syampurwadi, Procedia Chem, 4 268-274 (2012)

13. C. Zhang, L. Wang, J. Zhao, and P. Zhu, Adv. Mater. Res, 239-242 2667-2670 (2011)

14. P. Tang and G. Sun, Carbohydr. Polym, 160 153-162 (2017)

15. A. Retegi, N. Gabilondo, C. Peña, R. Zuluaga, C. Castro, P. Gañan, K. de la Caba, and I. Mondragon, Cellulose 17 661-669 (2010)

16. K. Padmavathi and K. Thangadurai, Indian J. Sci. Technol, 9 1-6 (2016)

17. H. Suryanto, P. T. Hutomo, R. Wanjaya, and P. Puspitasari, AIP International Proceding International Mechanical Engineering and Engineering Education (IMEEEC),030027-(1-4) (2016)

18. H. Suryanto, A. A. Fikri, A. A. Permanasari, U. Yanuhar, and S. Sukardi, J. Nat. Fibers, 15 406-415 (2018)

19. G. Cheng, P. Varanasi, C. Li, H. Liu, Y. B. Melnichenko, B. A. Simmons, M. S. Kent, and S. Singh, Biomacromolecules 12 933-41 (2011) 